\title{
Kapabilitas Dinamis UMKM dalam Merespons Perubahan Lingkungan Bisnis
}

\author{
Liliani $^{1}$, Jessy Wiliana ${ }^{2}$ \\ Internasional Business Management, Universitas Ciputra \\ e-mail: 11iliani@ciputra.ac.id, ${ }^{2}$ jessy.wiliana99@gmail.com
}

\begin{abstract}
This study aims to explore the extent to which the SMEs are capable to develop dynamic capabilities to actively response changes of the environment. Exploration is conducted to SMEs in Surabaya engaged in food and beverage in order to capture the dynamics of the business environment and the ability of the SMEs relevant to dynamic capabilities. Three capabilities, namely adaptive, absorptive and innovative capabilities will be used to represent the elements of dynamic capabilities. This study uses qualitative descriptive approach to illustrate the abilities of SMEs in facing dynamic environment. Data collection uses semi-structured interview to four informants, who are chosen using purposive sampling method. The informants must meet all criteria set in this study to ensure their competence to explain SMEs operational activities, strategies and business environment. The results of this study shows that the SMEs have engaged in business activities related to adaptive, absorptive and innovative capabilities, but the activities are not managed comprehensively nor continuously. This study amplify important points of consideration to develop dynamic capabilities in SMEs.
\end{abstract}

Keywords: dynamic capabilities, adaptive, absorptive, innovative, knowledge management

\section{PENDAHULUAN}

Keberadaan Usaha Mikro, Kecil dan Menengah (UMKM) memiliki peranan penting dalam menunjang perekonomian di Indonesia. UMKM merupakan salah satu sektor riil yang memiliki kontribusi signifikan dalam penyerapan tenaga kerja (Hafni \& Rozali, 2017). Sampai dengan awal tahun 2017, UMKM mampu menyerap tenaga kerja sebesar $96.71 \%$ serta berkontribusi sebesar lebih dari 60\% terhadap PDB Indonesia (Muharram, 2017). Berbagai upaya dilakukan oleh pemerintah untuk mendukung munculnya UMKM baru maupun mengembangkan UMKM yang sudah ada (Purwanti, 2012), di antaranya melalui program peningkatan daya saing UMKM yang diprioritaskan pada peningkatan kualitas produk, pengembangan keterampilan usaha, kewirausahaan dan pemberian fasilitas pembiayaan, kemudahan regulasi dan kemitraan (Muharram, 2017). Pertumbuhan UMKM yang optimal bukan hanya menjadi tanggung jawab pemerintah, namun para pelaku UMKM pun harus memiliki inisiatif untuk berkembang secara mandiri.

Tingginya persaingan menjadi tantangan tersendiri bagi UMKM untuk berkembang. Banyaknya pemain dalam suatu industri yang berusaha memberikan berbagai penawaran pada akhirnya menyebabkan sumber daya dan produk yang ditawarkan menjadi relatif sama. Demikian pula perubahan lingkungan bisnis yang dinamis mengakibatkan sumber daya dan kapabilitas unggulan yang ditawarkan menjadi usang. Lingkungan eksternal perusahaan yang cepat berubah telah menjadi bagian dari realitas bisnis masa kini yang tidak dapat dihindari. Hal ini dipicu oleh kecepatan informasi, kurva belajar yang lebih pendek untuk menemukan inovasi atau teknologi terbaru, perubahan faktor sosial ekonomi politik yang sulit diprediksi (Kristinawati, Jann, \& Tjakraatmadja, 2017). 
UMKM perlu meningkatkan kemampuan untuk bersaing yang lebih mengutamakan kemandirian sebagai bisnis murni (Sri, Strategi, \& Susilo, 2010). Beberapa upaya yang dapat dilakukan adalah dengan meningkatkan kemampuan kewirausahaan pemilik UMKM untuk menjalankan usaha dengan kreatif dan inovatif (Rosenbusch, Brinckmann, \& Bausch, 2011; Setyanto, Samodra, \& Pratama, 2016), serta mengembangkan kapabilitas untuk menghadapi perubahan dan ketidakpastian lingkungan bisnis. Dalam hal ini, kapabilitas merupakan serangkaian perilaku dan kemampuan yang dipelajari, terpola, dijalankan secara repetitif yang memungkinkan sebuah organisasi mampu menghasilkan performa yang lebih baik dibandingkan pesaingnya (Winter, 2003).

Kapabilitas dinamis menjadi pendekatan yang paling sesuai dengan lingkungan persaingan yang semakin dinamis (Teece et al., 1997; Wang dan Ahmed, 2007). Kapabilitas dinamis merupakan pola pikir terus mengintegrasikan, mengonfigurasi ulang, memperbarui dan menciptakan kembali kemampuan inti dalam menanggapi lingkungan yang terus berubah untuk mencapai dan mempertahankan keunggulan kompetitif (Wang \& Ahmed, 2007). Menurut Wang \& Ahmed (2007), kapabilitas dinamis dibangun melalui pengembangan tiga kapabilitas, yaitu: adaptif, absortif dan inovatif. Banyak penelitian yang telah membuktikan bahwa kapabilitas dinamis membantu UMKM untuk mempertahankan dan menciptakan kembali keunggulan kompetitif agar menjadi keunggulan kompetitif berkelanjutan yang berdasarkan lingkungan yang dinamis (Nedzinskas, Pundzienë, Buopiûtë-Rafanavièienë, \& Pilkienë, 2013; Wilhelm, Schlömer, \& Maurer, 2015).

Penelitian ini bertujuan mengeksplorasi sejauh mana potensi UMKM dalam mengem- bangkan kapabilitas dinamis. Eksplorasi secara khusus dilakukan pada UMKM di Surabaya yang bergerak di bidang makanan dan minuman. Hal ini dilakukan dengan mempertimbangkan luasnya lingkup penelitian, sehingga perlu adanya batasan ruang lingkup, selain itu, lingkungan bisnis dan kemampuan UMKM yang memungkinkan peneliti dapat memperoleh data di lapangan yang relevan untuk menggambarkan kapabilitas dinamis UMKM.

Industri makanan dan minuman di Indonesia saat ini adalah salah satu sektor yang penting dalam perekonomian di Indonesia. Data Kementerian Perindustrian menyebutkan, pada triwulan I tahun 2016, industri makanan dan minuman memberikan kontribusi terhadap Produk Domestik Bruto (PDB) sebesar Rp136,57 triliun atau memberikan kontribusi sebesar 31,4\% terhadap PDB industri pengolahan non-migas (Julianto, 2016). UMKM makanan kelompok fast moving enterprise yaitu UMKM yang mempunyai kemampuan kewirausahaan yang cakap dan telah siap bertransformasi menjadi usaha yang lebih besar (Bank Indonesia \& LPPI, 2015). Surabaya sebagai kota metropolitan kedua di Indonesia menyediakan peluang dan iklim usaha yang baik. Berdasarkan data Peringkat Izin Usaha PMDN kota Surabaya pada tahun 2017, pemberian izin usaha sektor makanan di Surabaya menduduki peringkat tertinggi dibanding sektor lain, yaitu sebesar 77,95\%, dengan nilai investasi mendekati Rp 1,3 miliar (Dinas Penanaman Modal \& PTSP Kota Surabaya, 2017). Hal ini menunjukkan banyaknya pemain di bisnis makanan, termasuk masuknya pemain baru. Selain itu, lingkungan bisnis yang dinamis, preferensi konsumen dan gaya hidup masyarakat yang cepat berubah menciptakan pasar yang dinamis yang mengharuskan pelaku bisnis memiliki kapabilitas dinamis untuk bertahan di situasi pasar yang selalu berubah. 
Berdasarkan latar belakang tersebut, maka penelitian ini difokuskan untuk menggali potensi pengembangan UMKM yang bergerak di sektor makanan, di Surabaya dalam merespons perubahan lingkungan bisnis, ditinjau dari perspektif kapabilitas dinamis. Rumusan masalah dalam penelitian ini adalah bagaimana kemampuan UMKM sektor makanan di Surabaya dalam merespons perubahan lingkungan bisnis?

Hasil penelitian ini diharapkan dapat menjadi referensi yang bermanfaat bagi pelaku UMKM, wirausaha, lembaga pengembangan UMKM dan menambah kajian terkait teori kapabilitas dinamis, manajemen usaha kecil dan inovasi.

\section{KAJIAN LITERATUR}

\section{Kapabilitas Dinamis}

Istilah kapabilitas menekankan aturan kunci dari manajemen dalam beradaptasi, mengintegrasi, dan merekonfigurasi secara tepat keterampilan-keterampilan internal dan eksternal organisasi, sumber daya, dan kompetensi fungsional untuk menyesuaikan dengan persyaratan perubahan lingkungan. Istilah dinamis menunjukkan kapasitas untuk memperbarui kompetensi-kompetensi untuk mencapai kesesuaian dengan perubahan lingkungan bisnis; tanggapan tertentu diperlukan ketika laju perubahan teknologi cepat, dan kompetisi mendatang dan kondisi pasar sulit ditentukan (Sriwidadi, 2014).

Konsep kapabilitas dinamis dikembangkan secara eksplisit dalam suatu studi oleh Teece, et al. (1997), yaitu kumpulan sumber daya, mekanisme di mana perusahaan melakukan pembelajaran dan mengakumulasi keterampilan dan kemampuan untuk mengintegrasi, membangun, dan merekonfigurasi kompetensi-kompetensi internal dan eksternal untuk menghadapi perubahan lingkungan yang cepat. Kapabilitas dinamis memiliki dimensi-dimensi pengindraan (sensing) kebutuhan untuk berubah, pembelajaran (learning) bagaimana menanggapi peluang dan ancaman dan pencapaian rekonfigurasi (reconfiguring) (Teece, 2007). Kapabilitas dinamis merupakan kebiasaan orientasi perusahaan yang secara konstan mengintegrasi, rekonfigurasi, memperbarui dan membangun kembali sumber daya dan kemampuan inti dalam merespons lingkungan yang berubah untuk mencapai dan mempertahankan keunggulan kompetitif (Wang \& Ahmed, 2007).

Menurut Wang \& Ahmed (2007) untuk memiliki kapabilitas dinamis, perusahaan harus memiliki tiga kemampuan yaitu adaptif, absorptif, dan innovatif.

\section{a. Kapabilitas Adaptif}

Kapabilitas adaptif adalah kemampuan untuk mengidentifikasi dan mengapitalisasi peluang yang muncul dari pasar dan dapat diukur dari kemampuan untuk merespons peluang, memonitor pasar, pelanggan dan pesaing, serta mengalokasikan sumber daya untuk kegiatan pemasaran (Hofer, Niehoff, \& Wuehrer, 2015; Sriwidadi, 2015). Kapabilitas adaptif membuat perusahaan mampu menyesuaikan diri terhadap perubahan lingkungan dan menyelaraskan sumber daya internal dengan permintaan eksternal yang penting untuk kelangsungan hidup serta evolusi perusahaan (Wang \& Ahmed, 2007). Perusahaan yang memiliki tingkat adaptif tinggi juga menunjukkan kemampuan dinamis (Teece, Pisano, \& Shuen, 1997).

\section{b. Kapabilitas Absorptif}

Kapabilitas absorptif didefinisikan sebagai kemampuan perusahaan untuk mengenali nilai 
baru, informasi eksternal, mengasimilasi, dan mengaplikasikan ke tujuan komersial. Kapabilitas ini dapat dilihat dari kemampuan untuk mengevaluasi dan menggunakan pengetahuan dari luar organisasi, seperti intensitas kegiatan penelitian dan pengembangan. (Wang \& Ahmed, 2007). Perusahaan dengan kemampuan penyerapan yang lebih tinggi menunjukkan kemampuan belajar yang lebih kuat dari mitra usahanya, mengintegrasikan informasi eksternal dan mengubahnya menjadi pengetahuan tertanam perusahaan. Kapabilitas absorptif bersifat multidimensi dan terdiri dari empat faktor pengetahuan: akuisisi, asimilasi, transformasi, dan eksploitasi (S. Zahra \& George, 2002).

Akuisisi mengacu pada kemampuan perusahaan untuk mengidentifikasi dan memperoleh pengetahuan dari eksternal untuk mendukung kegiatan operasional (S. Zahra \& George, 2002). Arah akuisisi dapat memengaruhi jalur yang diikuti perusahaan dalam memperoleh pengetahuan eksternal, sementara intensitas dan kecepatan usaha perusahaan untuk mengidentifikasi dan mengumpulkan pengetahuan dapat menentukan kualitas kemampuan akuisisi perusahaan.

Asimilasi mengacu pada rutinitas dan proses perusahaan yang memungkinkannya menganalisis, memproses, menafsirkan, dan memahami informasi yang diperoleh dari sumber eksternal (S. Zahra \& George, 2002). Pengetahuan eksternal juga bersifat konteks, yang seringkali mencegah orang luar untuk tidak memahami atau mereplikasi pengetahuan. Pemahaman sangat sulit bila nilai pengetahuan bergantung pada keberadaan aset pelengkap yang mungkin tidak tersedia bagi perusahaan lain.

Transformasi menunjukkan kemampuan perusahaan untuk mengembangkan dan menyempurnakan rutinitas yang memfasilitasi penggabungan pengetahuan yang sudah ada dengan pengetahuan yang baru diakuisisi atau diasimilasi (S. Zahra \& George, 2002). Hal ini dilakukan dengan menambah atau menghapus pengetahuan atau hanya dengan menafsirkan pengetahuan yang sama dengan cara yang berbeda.

Eksploitasi merupakan kemampuan organisasi didasarkan pada rutinitas yang memungkinkan perusahaan untuk memperbaiki, memperluas, dan memanfaatkan kompetensi yang ada atau menciptakan yang baru dengan menggabungkan pengetahuan yang diperoleh dan ditransformasikan ke dalam operasinya (S. Zahra \& George, 2002). Penekanan eksploitasi adalah pada rutinitas yang memungkinkan perusahaan mengeksploitasi pengetahuan, meskipun tidak tertutup kemungkinan perusahaan mungkin bisa memanfaatkan pengetahuan secara kebetulan, tanpa rutinitas yang sistematis.

\section{c. Kapabilitas Inovatif}

Kapabilitas inovatif merupakan kemampuan untuk mengembangkan produk atau pasar baru, melalui penyelarasan orientasi inovatif strategis dengan perilaku inovatif dan proses (Wang $\&$ Ahmed, 2004). Kapabilitas inovatif diukur dari jumlah inovasi produk atau jasa, inovasi proses, menemukan solusi permasalahan, pasar baru, sumber pasokan baru dan mengembangkan bentuk organisasi baru (Wang \& Ahmed, 2007). Kapabilitas inovatif dapat dijabarkan ke dalam dimensi inovasi produk atau layanan baru, metode produksi atau, pengambilan risiko oleh para eksekutif, dan mencari solusi baru yang tidak biasa (Hofer, Niehoff, \& Wuehrer, 2015).

\section{METODOLOGI PENELITIAN}

Penelitian ini menggunakan pendekatan kualitatif deskriptif untuk mendeskripsikan dan 
menganalisis fenomena, peristiwa, aktivitas sosial, sikap, kepercayaan, persepsi pemikiran orang secara individual maupun kelompok (Syaodih, Metode Penelitian Pendidikan, 2013). Dengan menggunakan pendekatan ini, peneliti dapat memperoleh gambaran yang lengkap dan menyeluruh mengenai kemampuan UMKM dalam menghadapi lingkungan yang dinamis.

Informan yang digunakan dalam penelitian ini dipilih dengan mempertimbangkan pengetahuan dan pemahaman informan untuk menggambarkan situasi yang sebenarnya mengenai objek penelitian (Bungin, 2015). Dalam penelitian kualitatif, tidak ditentukan jumlah sampel yang ideal untuk setiap penelitian, namun 4 sampai 10 dapat dikatakan jumlah yang ideal (Eisenhardt, 1989). Informan dalam penelitian ini terdiri pemilik dan pengelola dari 4 UMKM makanan di Surabaya yang dipilih dengan menggunakan sampel purposif. Informan harus memahami dan mampu menjelaskan mengenai kondisi internal, lingkungan eksternal UMKM dan memaparkan kemampuan UMKM dalam menghadapi perubahan lingkungannya. Oleh karena itu, kriteria pemilihan informan ditetapkan sebagai berikut: informan adalah pemilik atau pengelola UMKM dengan pengalaman minimal 3 tahun mengelola dan mengetahui tentang UMKM yang diteliti. Informan diharapkan dapat memberikan informasi mengenai innovative, absorptive, adaptive capability dari UMKM yang diteliti. UMKM yang diteliti adalah UMKM yang mempunyai kemampuan kewirausahaan yang cakap dan telah siap bertransformasi menjadi usaha yang lebih besar, memiliki manajemen dan organisasi yang baik, dengan pembagian tugas yang jelas seperti bagian keuangan, bagian pemasaran dan bagian produksi, memisahkan keuangan perusahaan dengan keuangan keluarga, telah memiliki persyaratan legalitas antara lain izin usaha, NPWP, beroperasi lebih dari 5 tahun. UMKM yang memenuhi kriteria ini diharapkan dapat menggambarkan kemampuan dalam menghadapi perubahan lingkungan bisnis.

Pengumpulan data dalam penelitian ini menggunakan wawancara semi struktur agar dapat menggali permasalahan secara lebih terbuka, di mana pihak yang diajak wawancara diminta pendapat, dan ide-idenya (Sugiyono, 2015). Wawancara dilakukan menggunakan pedoman wawancara disusun sedemikian rupa sehingga memiliki alur pertanyaan yang dimulai dari hal-hal yang mudah dijawab responden lalu mengerucut pada hal yang lebih kompleks (Bungin, 2015). Untuk memperoleh keabsahan data dan menghindari bias, maka peneliti menggunakan member checking. Metode ini memungkinkan peneliti untuk mengontrol kualitas penelitian kualitatif, memperbaiki akurasi, kredibilitas, reabilitas dan validitas data wawancara (Harper \& Cole, 2012).

Penelitian ini menggunakan teknik deskriptif untuk analisis data yang dilakukan dengan tahapan reduksi, penyajian dan penarikan kesimpulan (Sugiyono, 2015). Reduksi data dilakukan dengan merangkum, memfokuskan pada hal-hal yang dianggap penting, mencari tema dan pola yang menggambarkan kapabilitas adaptif, absorptif dan inovatif. Penyajian data menggunakan uraian deskriptif atas hasil wawancara yang sudah diolah dan diringkas untuk menjawab rumusan masalah. Tahap terakhir dalam analisis data adalah dengan menarik kesimpulan atau melakukan verifikasi terhadap temuan yang menjawab rumusan masalah.

\section{PEMBAHASAN}

Penelitian dilakukan pada empat UMKM makanan yang berlokasi di Surabaya dan telah 
memenuhi kriteria yang ditetapkan, yaitu Wei Xiao, Wisata Rasa, Katering \& Depot 88 dan Gudeg Putri Bu Har. Paragraf berikut ini menjelaskan gambaran umum masing-masing UMKM.

Wei Xiao didirikan pada tahun 2012 oleh Jennifer Smith yang memiliki latar belakang pendidikan bisnis manajemen. Wei Xiao adalah restoran Chinese Fast Food yang telah memiliki 3 cabang yaitu di Loop Graha Family, UC Walk Citraland dan Sekolah Cita Hati Surabaya. Wei Xiao memilih target pasar anak muda dengan fokus pada masakan Chinese food yang disesuaikan dengan kebutuhan dan selera anak muda sekarang dengan penyajian yang cepat.

Wisata Rasa adalah toko oleh-oleh khas Surabaya berdiri pada tahun 2004. Wisata rasa merupakan toko oleh-oleh yang berkonsep modern dan nyaman dan saat ini telah memiliki 5 gerai di Kota Surabaya, 1 cabang di Kota Sidoarjo dan 1 cabang di Kota Malang. Toko Wisata Rasa menjadi destinasi belanja camilan dan oleholeh khas daerah baik bagi penduduk Kota Surabaya maupun bagi para wisatawan yang berkunjung ke Kota Surabaya.

Katering 88 berdiri pada tahun 1995 dan mulai membuka depot 2 tahun setelahnya. Target konsumen Katering \& Depot 88 adalah keluarga, khususnya masyarakat keturunan Tionghoa. Makanan yang dijual bercita rasa Chinese Food dan mengandung babi dengan porsi makanan cukup besar sehingga cocok untuk dinikmati bersama keluarga. Menu andalan mereka adalah udang tauco dan ayam goreng 88 .

Gudeg Bu Har berdiri dari generasi pertama pada tahun 1970 dan saat ini Gudeg Bu Har berganti nama menjadi Gudeg Putri Bu Har karena sudah dikelola oleh putri Bu Har yaitu Bu Hardi. Saat ini, Gudeg Putri Bu Har sudah menjalankan usahanya sampai generasi ketiga.
Target konsumen Gudeg Putri Bu Har adalah warga kota Surabaya yang berpenghasilan menengah.

\section{Diskusi}

Bagian ini akan menguraikan kemampuan UMKM dalam merespons perubahan lingkungan eksternalnya dengan mengacu pada tiga elemen kapabilitas dinamis, yaitu kapabilitas adaptif, absorptif dan inovatif. Selanjutnya akan diuraikan bagaimana ketiga elemen tersebut membentuk kapabilitas dinamis yang memungkinkan UMKM merespons perubahan lingkungan dengan baik. Bagian terakhir dari pembahasan akan menjelaskan implikasi penelitian ini bagi upaya pengembangan UMKM, khususnya dalam merespons perubahan lingkungan.

\section{Kapabilitas Adaptif}

Dari hasil pengamatan dan wawancara, UMKM makanan di Surabaya dapat merespons peluang, memonitor pasar, memindai konsumen serta pesaing. Pemilik UMKM dapat mengidentifikasi pasar agar usaha mereka dapat diterima oleh konsumen. Tindakan pemilik/pengelola UMKM dalam merespons peluang disesuaikan dengan sumber daya yang dimiliki. Hal ini membuat UMKM dapat memasarkan produk dengan baik karena menawarkan nilai lebih. Berikut ini kutipan wawancara dengan informan:

“...jadi aku tau banget target pasarku siapa, aku tau banget apa nama ne eee daya beli mereka gimana.. aku mencoba dari yang paling dekat dulu yaitu lingkunganku..." (JS-3).

"Eee kita toko oleh-oleh pertama yang membranding khas Surabaya. Dulu itu semuanya branding khas Jawa Timur.. lha yang lain pemain lain pada mulai ikutan... Wisata Rasa kan outlet-nya banyak jadi mempermudah visitor-visitor Surabaya itu buat ndapetin oleh-oleh..." (BM-21, 37). 
Kegiatan mencari peluang baru, evaluasi pasar dan pesaing, dilakukan sebatas pada saat dibutuhkan, yaitu pada saat akan membuka usaha, membuka cabang baru dan hanya berfokus membidik peluang dan pasar yang sama dari awal memulai perusahaan. Sebagai contoh, Gudeg Putri Bu Har melihat peluang pasar di mana pada awal membuka usaha belum ada gudeg yang sesuai dengan lidah orang Surabaya dan berbeda dengan gudeg Jogja.

“... Usaha ibu ini spesialis masakan gudeg tapi yang sesuai dengan lidah anak Suroboyo ga terlalu manis kaya gudegnya orang Jogja lalu kuahnya cukup kental... (BH-2)".

UMKM belum melakukan aktivitas tersebut sebagai aktivitas rutin yang menjadi budaya perusahaan dan belum membidik peluang lain yang ada di pasar. Padahal kapabilitas adaptif tidak hanya dilakukan apabila dibutuhkan karena perubahan lingkungan, namun idealnya tertanam dalam proses di perusahaan (Wang \& Ahmed, 2007). Namun, ada satu UMKM, yaitu Depot $\&$ Katering 88 yang memonitor pasar dan mulai mengalokasikan sumber daya mereka untuk menjawab peluang dari target konsumen generasi muda dengan membuka cafe yang berbeda dari target konsumen lama mereka. Hal ini menunjukkan bahwa UMKM mampu mengembangkan kapabilitas adaptif dengan mulai memberikan fokus pada target pasar lain, mengeksploitasi dan mengeksplorasi sumber daya lain untuk memajukan perusahaan (Wang \& Ahmed, 2007).

Data yang diperoleh di lapangan menunjukkan evolusi organisasi pada UMKM belum tampak perbedaan yang signifikan dibanding saat didirikan. UMKM tersebut juga belum memiliki aset perusahaan seperti aset organisasi, pemasaran dan teknis yang memiliki efek positif yang kuat terhadap strategi perusahaan. Strategi yang dimaksud seperti diferensiasi inovatif, pemasaran dan biaya rendah dinilai kurang sehingga sumber daya yang ada tidak menghasilkan strategi pengembangan yang lebih kompleks dan menguntungkan perusahaan Amit \& Schoemaker, 1993; Spanos \& Lioukas, 2001(dalam Wang \& Ahmed, 2007). Pengembangan kemampuan yang berkelanjutan juga kurang pada UMKM yang diteliti dikarenakan kurangnya fokus UMKM pada strategi jangka panjang perusahaan. Padahal fokus pada pengembangan strategi perusahaan dapat membangun kemampuan perusahaan dalam memantau konsumen, pasar dan pengembangan knowledge based yaitu sumber daya non fisik seperti kompetensi, teknologi, pengetahuan, keterampilan, pengalaman perusahaan yang menjadi faktor krusial untuk unggul dari kompetitor dalam sumber daya (Tjakaraatmadja \& Kristinawati, 2017).

UMKM yang diteliti berperan sebagai reaktor dan analisator. Menurut Miles \& Snow, 1978 (dalam Wang \& Ahmed, 2007), reaktor adalah perusahaan yang tidak memiliki proses internal untuk mengidentifikasi dan merespons peluang pasar, sedangkan analisator adalah perusahaan yang menunjukkan beberapa kemampuan beradaptasi, walaupun mereka cenderung tetap berada di pasar produk yang relatif stabil, mereka memantau perubahan pasar dengan tujuan untuk mengidentifikasi dan mengejar peluang baru. Kapabilitas adaptif sebaiknya diarahkan kepada peran sebagai prospectors, di mana perusahaan terus mencari peluang pasar, produk baru, dan saat mereka mengembangkan, mereka mempertahankan kemampuan untuk mengejar peluang.

Berdasarkan fakta yang ditemukan di lapangan, dapat dilihat bahwa UMKM memang belum memiliki kapabilitas adaptif yang tinggi. Dampak untuk UMKM yang tidak memiliki kapabilitas adaptif yang tinggi adalah tidak ada 
kemampuan untuk mengeksploitasi dan mengeksplorasi strategi lain serta sumber daya lain untuk memajukan perusahaan (Wang \& Ahmed, 2007).

\section{Kapabilitas Absorptif}

Dari hasil wawancara, ditemukan bahwa UMKM tidak memiliki kegiatan khusus yang dilakukan perusahaan untuk belajar pengetahuan potensial dari dalam maupun luar perusahaan. Proses akuisisi pengetahuan yang terjadi di Wei Xiao dan Wisata Rasa dilakukan melalui pengamatan terhadap pesaing.

“...pokoknya kalo ke resto duduk-duduk deket dapur, duduk deket tempat kasir .. jadi aku belajar dari mereka ya'apa caranya...."(JS-25)

"orang tuaku pernah ngamati 1 toko oleh-oleh ... nah itu tiap liburan employeenya kayak diajak pergi... Jadi itu mulai kita tiru itukan bagus untuk meningkatkan loyalty-nya employee." (BM-81, H C-26 )

Dari hasil wawancara, peneliti menemukan kurangnya inisiatif UMKM untuk menerapkan pengetahuan dari luar karena informan berpandangan bahwa sistem yang telah berjalan sudah mencukupi untuk menjalankan kegiatan operasional. Penyerapan pengetahuan dari luar hanya dilakukan sebagai langkah korektif bila terjadi kekurangan pada sistem yang sudah berjalan, dan belum ada kegiatan yang dikhususkan untuk menambah pengetahuan untuk memajukan perusahaan.

Kapabilitas absorptif memiliki empat dimensi yaitu akuisisi, asimilasi, transformasi, dan eksploitasi (Zahra \& George, 2002). Dimensidimensi ini saling membangun untuk menghasilkan kapabilitas dinamis yang koheren, yang mendorong perubahan dan evolusi organisasi. Saat ini UMKM yang diteliti baru memiliki dimensi akuisisi, yang ditunjukkan dengan ada- nya penyerapan pengetahuan dari luar perusahaan. UMKM belum melakukan asimilasi dan transformasi. Hal ini tampak dari data yang diperoleh, yaitu UMKM belum secara rutin memproses informasi yang diperoleh dari sumber eksternal, belum optimal mengembangkan dan menyempurnakan pengetahuan menjadi aset yang sulit direplikasi oleh kompetitor (Zahra, 2002). Kemampuan belajar yang kurang menghambat tumbuhnya pengetahuan sebagai aset perusahaan (Tseng \& Lee, 2014) dan pada akhirnya tidak menghasilkan peningkatan kinerja maupun pengembangan perusahaan yang berarti (Zahra \& George, 2002; Wang \& Ahmed, 2007). Dari hasil wawancara dapat dilihat bahwa pemilik UMKM melakukan eksploitasi pengetahuan untuk memperbaiki operasional perusahaan pada batasan meniru kegiatan operasional maupun pengembangan produk kompetitor. Sebagai contoh, eksploitasi untuk memperbaiki rutinitas dilakukan UMKM Wei Xiao dengan mengajak para karyawannya untuk mengembangkan rasa memiliki melalui kegiatan outing dan melakukan evaluasi kinerja bulanan. Sementara itu, Depot \& Katering 88 melakukan transformasi memperbaiki rutinitas yang ada dengan benar-benar menjaga kebersihan produk yang mereka setelah mengakuisi pengetahuan dari pesaing yang produknya dinilai kurang memuaskan dari segi kebersihan.

\footnotetext{
“...menumbuhkan rasa memiliki mereka terhadap Wei Xiao dengan kayak aku satu tahun sekali ada outing...” ( JS-24, H C-7).

"Ya aku lah, tapi kalo iri-irian tengkar gitu emang kadang aku selesainya setiap bulan evaluasi bulanan...” (JS-53, H C-12).

“....Kalo yang ikan-ikan atau ayam itu kebersihan harus diperbaiki diperhatikan jangan sampe ada bulu..." (A-40, H C-40)".
}

Eksploitasi belum dilakukan secara optimal karena tidak dilandasi kemampuan asimilasi 
dan transformasi pengetahuan yang memadai. Hasilnya adalah setiap perusahaan memiliki persamaan dalam kemampuan namun kuncinya agar dapat lebih unggul dari perusahaan lain adalah keunggulan kompetitif perusahaan dalam identifikasi dan merespons isyarat lingkungan dengan baik sebelum hasil kinerja yang berorientasi, namun perbedaan kinerja muncul dari berbagai jalur perkembangan yang diikuti perusahaan dan waktu penerapan kemampuan (Zahra \& George, 2002).

\section{Kapabilitas Inovatif}

Inovasi memiliki 5 area utama, yaitu inovasi produk, inovasi pasar, inovasi proses, inovasi kebiasaan, dan inovasi strategis. Inovasi produk dan pasar memiliki keterkaitan secara langsung yang berdampak pada eksternal perusahaan sedangkan inovasi proses, kebiasaan dan strategis berhubungan dengan internal perusahaan (Wang \& Ahmed, 2004). Dari empat UMKM yang diteliti, dua UMKM, yaitu Wei Xiao dan Wisata Rasa melakukan inovasi produk, proses dan layanan, sementara dua UMKM lain hanya melakukan perbaikan pada kegiatan operasional. Inovasi yang dilakukan Wei Xiao berupa variasi produk dan perbaruan produk secara rutin, sedangkan Wisata Rasa yang memiliki produk camilan khas mengembangkan proses produksi yang lebih efisien.

"Kalo inovasi ya... sekarang menuku 50 aja lebih jadi aku setiap 6 bulan sekali aku selalu mikirin mau ngasih menu apa buat apa untuk upgrade menuku" (JS-34)

"Ada. Khusus Almond Cheese. Ada booth toko oleh-oleh pertama kita di mall yawes di Atom itu..." (BM-61)

"Kalo mau dibilang inovasi gimana ya, ehhm dulu awal-awal produksi itu cuma sehari bisa bikin berapa jadi 1 resep tok... Nah papi ku itu dulu bisa nemuin cara supaya produksi produktivitas'e meningkat kayak sekali bikin itu bisa bikin berapa resep sekaligus" (BM-86).

\section{Pemilik Depot \& Katering 88 dan Gudeg} Putri $\mathrm{Bu}$ Har belum melakukan inovasi tetapi telah melakukan pengembangan produk, administrasi dan berusaha memberikan layanan yang lebih nyaman bagi pelanggan. Hal ini dapat dilihat dari kutipan wawancara berikut.

"Lebih baik ya kalo kaki 5 kan ya orang mau makan pun sulitlah mau parkir mau parkirnya sulit kalo imagenya kan juga beda ya kalo kita buka di ruko kalo di Gwalk itu wes parkirnya bagus..." (A-43).

"Oh ibu beri variasi untuk menyajikan gudeg ibu, gudeg ibu variasikan dengan pecel” (BH-13). "Ya sama nik masih sama tidak berubah tapi kita selalu membuat perubahan untuk pelanggan ibu nyaman kembali, seperti ini tempat makannya dulu ini belum pakai ac... Dulu juga nota masih tulis tangan sekarang sudah mulai pakai mesin kasir" (BH-6).

Para pemilik UMKM telah mencoba melakukan inovasi dan upaya pengembangan usaha, namun hal tersebut masih perlu dioptimalkan lagi. Kapabilitas inovatif perusahaan bergantung pada pengetahuan yang dimilikinya, dan juga kemampuannya untuk menerapkannya (Saunila, 2016). Hal yang perlu dilakukan adalah lebih memperhatikan fitur penting dari inovasi, antara lain mempertimbangkan sejauh mana produk baru dipandang bermanfaat bagi konsumen, didasari hasil riset pasar, menerapkan metode produksi, manajemen dan teknologi baru, budaya keterbukaan terhadap gagasan dan inovasi baru, mengidentifikasi kesenjangan dalam posisi industri dan mengarahkan sumber daya secara kreatif untuk menangkap peluang jangka panjang (Wang \& Ahmed, 2004). UMKM makanan harus membangun kapabilitas inovatif bukan hanya untuk menciptakan pelayanan ataupun produk baru namun juga memperbaiki visi dan strategi perusahaan, mengembangkan bentuk serta kemam- 
puan organisasi untuk berubah dan menciptakan nilai tambah yang baru kepada konsumen. Dengan demikian, konsumen menjadi loyal dan UMKM dapat menciptakan keunggulan kompetitif daripada sekadar membuat produk dan layanan yang dapat mudah ditiru pesaing.

\section{Merespons Perubahan melalui Kapabilitas Dinamis}

Berkenaan dengan rumusan masalah yang ditetapkan dalam penelitian ini, yaitu bagaimana kemampuan UMKM sektor makanan di Surabaya dalam merespons perubahan lingkungan bisnis, maka dapat dilihat bahwa pendekatan kapabilitas dinamis berpotensi membantu UMKM mengembangkan sejumlah kemampuan yang penting untuk memiliki keunggulan kompetitif (Evers, 2011; Newbert, 2005). Kapabilitas dinamis penting bagi UMKM untuk masuk ke dalam industri, beradaptasi untuk menciptakan pertumbuhan dan menjaga keberlangsungan usaha (Shaker A. Zahra, Sapienza, \& Davidsson, 2006).

Kapabilitas dinamis dapat dicapai perusahaan dengan membangun tiga kapabilitas, yaitu adaptif, absorptif dan inovatif, yang berjalan secara seimbang agar perusahaan dapat beradaptasi, mengintegrasi, dan mengonfigurasi secara tepat keterampilan-keterampilan internal dan eksternal organisasi, sumber daya, dan kompetensi fungsional untuk menyesuaikan dengan persyaratan perubahan lingkungan (Wang \& Ahmed, 2007). Berdasarkan hasil analisis data, dapat dilihat bahwa UMKM yang diteliti memang belum optimal dalam merespons perubahan lingkungan, namun UMKM telah menunjukkan kemampuan yang potensial untuk berkembang dengan melakukan perbaikan pada manajemen dan operasional perusahaan.

Ditinjau dari perspektif kapabilitas adaptif, UMKM hanya mengidentifikasi pasar saat mem- buka, memperluas usaha atau saat merasa membutuhkan. Implikasi dari temuan ini adalah UMKM perlu kapabilitas adaptif yang tertanam dalam proses internal perusahaan dalam bentuk/ struktur organisasi yang jeli melihat peluang dan pasar, mengontrol strategi, memajukan internal perusahaan untuk menangkap peluang eksternal (Wang \& Ahmed, 2007).

Ditinjau dari perspektif kapabilitas absorptif, UMKM kurang memaksimalkan kemampuan internal perusahaan, belum melakukan kegiatan khusus untuk menyerap pengetahuan dari luar perusahaan. Implikasi dari temuan ini adalah UMKM harus mempunyai kemauan yang kuat untuk berkembang, pemilik dan pengelola harus secara rutin melakukan kegiatan yang dikhususkan untuk belajar dalam hal apa pun dari luar perusahaan. Setelah itu, UMKM harus mempraktikkan pengetahuan dari luar untuk mengembangkan perusahaan secara berkelanjutan. Kemampuan untuk menyerap pengetahuan dari luar akan mendorong perusahaan memperbaiki kinerja dan menghasilkan inovasi (Rufaidah \& Sutisna, 2015; Wang \& Ahmed, 2007).

Ditinjau dari perspektif kapabilitas inovatif, saat ini UMKM hanya memberi variasi untuk menjawab kejenuhan pasar, cenderung sekadar mengikuti tren. Implikasi dari temuan ini adalah UMKM harus memiliki fokus menciptakan value jangka panjang pada produk/jasa. Kapabilitas inovasi yang baik dapat dibangun dengan memiliki kapabilitas adaptif dan absorptif yang baik (Zahra \& George, 2002). UMKM juga perlu mempunyai orang yang khusus untuk memantau dan menciptakan inovasi pada internal dan eksternal perusahaan, seperti bagian kreatif, bagian pengembangan produk.

Kapabilitas dinamis merupakan faktor kunci dalam mengoptimalkan arah strategis masa depan perusahaan (Teece, 2010). Walaupun 
perusahaan telah menyadari kebutuhan untuk berubah, namun sering kali perusahaan tidak memiliki kemampuan dan sumber daya untuk mengelola perubahan tersebut. Para pemilik dan pengelola UMKM perlu memperhatikan risiko karena ketidakpastian perubahan pasar dan sumber daya perusahaan (Wang \& Ahmed, 2004; Shaker A. Zahra et al., 2006). UMKM harus memiliki budaya belajar sebagai budaya organisasi karena proses pembelajaran yang berevolusi dapat memperkuat kapabilitas dinamis perusahaan (Eisenhardt \& Martin, 2000; McKelvie \& Davidsson, 2009; Shaker a. Zahra et al., 2006).

\section{SIMPULAN}

Berdasarkan pembahasan di atas, dapat disimpulkan bagaimana kemampuan UMKM sektor makanan di Surabaya dalam merespons perubahan lingkungan bisnis dengan menggunakan pendekatan kapabilitas dinamis. Dari ketiga elemen kapabilitas dinamis, yaitu kapabilitas adaptif, absorptif dan inovatif, UMKM telah melakukan aktivitas bisnis yang terkait dengan kapabilitas tersebut, namun aktivitas tersebut belum dikelola dengan baik dan terus-menerus. UMKM dapat melihat lalu merespons perubahan melalui imitasi dan perbaikan berorientasi pada tujuan taktis jangka pendek. Dengan demikian, dapat dikatakan bahwa UMKM belum memiliki kapabilitas dinamis secara menyeluruh.

Dari hasil penelitian ini, disarankan bagi UMKM untuk membangun kapabilitas dinamis melalui kapabilitas adaptif, absorptif, dan inovatif. Kemampuan kunci untuk membangun kapabilitas dinamis adalah kemampuan belajar. UMKM perlu mengelola pembelajaran menjadi budaya organisasi, membangun knowledge base sebagai aset perusahaan. Pada akhirnya UMKM perlu mengembangkan visi dan strategi jangka panjang, kemudian menggunakan knowledge base untuk memperbaiki kinerja, menghasilkan inovasi dan menciptakan keunggulan mampu berevolusi selaras dengan perubahan.

Penelitian ini menggambarkan kapabilitas dinamis melalui wawancara dan pengamatan di empat UMKM bidang makanan di Surabaya. Oleh karenanya, penelitian ini memiliki keterbatasan, di mana hasil penelitian tidak dapat digeneralisasikan untuk UMKM lain atau pada lingkup objek penelitian yang lebih luas. Bagi penelitian selanjutnya, diharapkan dapat mengembangkan penelitian terkait kapabilitas dinamis pada lingkup penelitian yang lebih luas. Beberapa topik yang dapat diteliti antara lain implementasi kapabilitas dinamis dengan memperhatikan kapabilitas operasional perusahaan, membandingkan kapabilitas dinamis pada skala usaha atau industri yang berbeda serta mengembangkan rumusan untuk membangun kapabilitas dinamis bagi perusahaan di Indonesia.

\section{REFERENSI}

Amit, R. \& Schoemaker, P.J. 1993. Strategic Assets and Organizational Rent. Strategic Management Journal, 14(1), 33-46.

Bungin, B. 2015. Metodologi Penelitian Sosial \& Ekonomi. Jakarta: Prenadamedia Group. Bank Indonesia. 2015. Profil Bisnis Usaha Mikro, Kecil, dan Menengah (UMKM). Jakarta.

Dinas Penanaman Modal \& PTSP Kota Surabaya. 2017. Peringkat Izin Usaha PMDN Berdasarkan Sektor Pada Tahun 2017 Kota Surabaya. http://dpm-ptsp.surabaya.go.id/ data_ investasi/pmapmdn/hasil1.php?jns= realisasi_investasi\&data $=$ PMDN\&th $=2017 \&$ kat $=$ sektor\&tri=semua diakses 20 Desember 2017. Eisenhardt, K.M. (1989). Building theories from case study research. Acad- 
emy of Management Review, 14 SRC-(4), 532-550.

Eisenhardt, K.M. \& Martin, J.A. 2000. Dynamic Capabilities: What are they? Strategic Management Journal, 21(10/11), 1105-1121.

Evers, N. 2011. International New Ventures in "Low Tech" Sectors: a Dynamic Capabilities Perspective. Journal of Small Business and Enterprise Development, 18(3), 502528.

Hafni, R. \& Rozali, A. 2017. Analisis Usaha Mikro, Kecil, dan Menengah (UMKM) terhadap Penyerapan Tenaga Kerja di Indonesia. Ilmu Ekonomi dan Studi Pembangunan, 15(2), 77-96.

Harper, M. \& Cole, P. 2012. Member Checking: Can Benefits be Gained Similar to Group Therapy? 1-2.

Hofer, K.M., Niehoff, L.M., \& Wuehrer, G.A. 2015. The Effects of Dynamic Capabilities on Value-Based Pricing and Export Performance. Entrepreneurship in International Marketing.

Kristinawati, D., Jann, D., \& Tjakraatmadja, H. 2017. Studi Konseptual Eksploratif Mengenai Hubungan Kapabilitas Dinamis dengan Kinerja Perusahaan. Jurnal Manajemen Indonesia, 17(1).

Julianto, P.A. 2016. Kompas. Diambil Kembali dari Ekonomi Kompas, Juli 21: http:// ekonomi.kompas.com/read/2016/07/21/ 203632226/menperin.industri.makanan. dan.minuman.strategis.bagi.perekonomian. nasional.

McKelvie, A. \& Davidsson, P. 2009. From Resource Base to Dynamic Capabilities: an Investigation of New Firms. British Journal of Management, 20, S63-S80.
Muharram, A. 2017. Arah Kebijakan Bidang Koperasi dan Usaha Mikro, Kecil, dan Menengah. Denpasar.

Nedzinskas, Đ., Pundzienë, A., BuopiûtëRafanavièienë, S., \& Pilkienë, M. 2013. The Impact of Dynamic Capabilities on SME Performance in a Volatile Environment as Moderated by Organizational Inertia. Baltic Journal of Management, 8(4), 376-396.

Newbert, S.L. 2005. New Firm Formation: A Dynamic Capability Perspective*. Journal of Small Business Management, 43(1), 5577.

Purwanti, E. 2012. Pengaruh Karakteristik Wirausaha, Modal Usaha, Strategi Pemasaran Terhadap Perkembangan UMKM di Desa Dayaan dan Kalilondo Salatiga. Among Makarti, 5(9), 13-28.

Rosenbusch, N., Brinckmann, J., \& Bausch, A. 2011. Is Innovation always Beneficial? A Meta-Analysis of the Relationship between Innovation and Performance in SMEs. Journal of Business Venturing, 26, 441457.

Rufaidah, P. \& Sutisna. 2015. Kapabilitas Dinamis UMKM Industri Kreatif Jawa Barat. Sosiohumaniora, 17(1), 60-66.

Saunila, M. 2016. Performance Measurement Approach for Innovation Capability in SMEs. International Journal of Productivity and Performance Management, 65(2), 162-176.

Setyanto, A.R., Samodra, B.R., \& Pratama, Y.P. 2016. Kajian Strategi Pemberdayaan UMKM dalam Menghadapi Perdagangan Bebas Kawasan ASEAN (Studi Kasus Kampung Batik Laweyan). ETIKONOMI, 14(2). Sri, Y., Strategi, S., \& Susilo, Y.S. 2010. Strategi Meningkatkan Daya Saing UMKM dalam 
Menghadapi Implementasi CAFTA dan MEA. Buletin Ekonomi Agustus, 8(2), 70170.

Sriwidadi, T. 2014. Pengaruh Kepemimpinan dan Kapabilitas Dinamis terhadap Manajemen Pengetahuan di Binus University Jakarta. The Winners, 15(1), 47.

Sugiyono. 2015. Metode Penelitian Kuantitatif. Bandung: Alfabeta.

Syaodih, N. 2013. Metode Penelitian Pendidikan. Bandung: Penerbit Alfabeta.

Teece, D., Pisano, G., \& Shuen, A. 1997. Dynamic Capabilities and Strategic Management. Strategic Management Journal, 509533.

Teece, D.J. 2007. Explicating Dynamic Capabilities: The Nature and Microfoundations of (Sustainable) Enterprise Performance. Strategic Management Journal Strategie Management Journal Streit. Mgmt, 28(28), 1319-1350.

Teece, D.J. 2010. Business Models, Business Strategy and Innovation. Long Range Planning, 43(2-3), 172-194.

Tseng, S.M., \& Lee, P.S. 2014. The Effect of Knowledge Management Capability and Dynamic Capability on Organizational Performance. Journal of Enterprise Information.
Wang, C.L. \& Ahmed, P.K. 2004. The Development and Validation of the Organizational Innovativeness Construct Using Confirmatory Factor Analysis. European Journal of Innovation Management, 7(4), 303313.

Wang, C.L. \& Ahmed, P.K. 2007. Dynamic Capabilities: A review and research agenda. International Journal of Management Reviews International Journal of Management Reviews IJMR International Journal of Management Reviews, 9(1), 31-51.

Wilhelm, H., Schlömer, M., \& Maurer, I. 2015. How Dynamic Capabilities Affect the Effectiveness and Efficiency of Operating Routines Under High and Low Levels of Environmental Dynamism. British Journal of Management, 26(2).

Winter, S.G. 2003. Understanding Dynamic Capabilities. Strategic Management Journal, 24(10 SPEC ISS.), 991-995.

Zahra, S.A., Sapienza, H.J., \& Davidsson, P. 2006. Entrepreneurship and Dynamic Capabilities: A Review, Model and Research Agenda. Journal of Management Studies, 43(4), 917-955.

Zahra, S. \& George, G. 2002. Absorptive Capacity: a Review, Reconceptualization, and Extension. The Academy of Management Review, 27(2), 185-203. 
Business and Finance Journal, Volume 3, No. 1, March 2018 